\title{
Morphological plasticity in a wild freshwater fish, Systomus sarana (Cyprinidae) from India: a glimpse through advanced morphometric toolkits
}

\section{Deepmala Gupta}

University of Lucknow Faculty of Science

Arvind Kumar Dwivedi

Barkatullah Vishwavidyalaya Faculty of Life Sciences

Madhu Tripathi ( $\sim$ drmtripathi@gmail.com )

University of Lucknow Faculty of Science https://orcid.org/0000-0003-1618-4994

\section{Research article}

Keywords: Intraspecies diversity, Morphological variations, Systomus sarana, Landmark based analysis

Posted Date: November 5th, 2020

DOl: https://doi.org/10.21203/rs.3.rs-35594/v2

License: (c) (i) This work is licensed under a Creative Commons Attribution 4.0 International License.

Read Full License 


\section{Abstract}

Background: Body morphology supposed to underpin wide differences in animal performance that can be used to understand the diversification of characters. Further, identifying the fish population with unique shape due to variations in their morphometric characters enable better management of these subunits. Advanced statistical toolkits of morphometry called truss network system and geometric morphometrics have been increasingly used for detecting variations in morphological traits between subunits of fish populations. The present study was therefore carried out with the objective of determining phenotypically distinct units of freshwater fish Systomus sarana collected from geographically isolated locations.

Methods: In the present study, 154 specimens of olive barb, $S$. sarana were collected from four distantly located rivers covering the northern (Ganga), southern (Godavari), central (Narmada), and eastern (Mahanadi) regions of India. Truss-network system and geometric morphometrics have been utilized. Fourteen landmarks were digitized uniformly on each specimen. In the present study, the truss network system yielded size-corrected morphometric characters that were subjected to univariate and multivariate statistical assessment.

Results: Analysis of variance (ANOVA) presented significant differences among 63 out of 90 variables $(p<0.05)$. Truss approach includes principal component analysis (PCA) and discriminant function analysis (DFA) while the geometric approach includes PCA, DFA, canonical variate analysis (CVA), partial least square (PLS), the relative warp (RW), and wireframes. CVA extracted Mahalanobis and Procrustes distances among groups found to be highly significant $(p<0.0001)$. In linear DFA, the overall assignment of correctly classified individuals into their original groups was $86.2 \%$ for Ganga, $86.1 \%$ for the Godavari, 93.9\% for the Narmada, and $92.9 \%$ for the Mahanadi population.

Conclusions: The results revealed significant variations in the morphometric characters which were reflected in the shape of different body features of the studied populations. Both methods revealed analogous results and significant differences among groups in examined features. Our results suggest that $S$. sarana shows morphological plasticity across different rivers in India. This study supports the concept that geographical isolation among fish populations can lead to morphological variations.

\section{Introduction}

Morphologically similar populations thriving together in a region are not easily distinguishable. Therefore, it is essential to recognize characters that differentiate populations. Morphological characters are capable of offering a foundation for population structure (Ihssen et al. 1981; Petrtyl et al. 2014). Further, the study of these characters with intends to differentiate fish population units has recently got much attention in ichthyology (Yusuf and Belduz 2009; Dwivedi 2019). Environmentally induced morphological variations provide clues related to fish population identities (Clayton 1981) which is essential from diverse perspectives including evolution, ecology, conservation, and also for managing water resources (AnvariFar et al. 2011). Morphological variations among populations can be assessed by traditional 
morphometric analysis (Turan 1999). Though this traditional approach is considered as a standard technique for species characterization, this method might not be useful for discriminate species when there is morphological plasticity (Takács et al. 2016). Advance statistical toolkits such as the truss network system and geometric morphometrics allow discrimination of species/population through the shape analysis of a whole or only fragment of structure to find the unidentified pattern of importance. These techniques have gained wide acceptance as tools in population studies and can potentially be used as low cost, accurate and precise tools, (Bookstein 1991; Rohlf 1990; Rohlf and Marcus 1993, Strauss and Bookstein 1982).

Interestingly, studies on intra-species morphological differentiation are essential in solving the problems related to species recognition, as it is agreed that insufficient information on intra-species geographic dissimilarities can lead to incorrect species identification (Ishihara 1987). Taxonomy is important to fishery scientists for the delineation of fish resources, and aids in developing balanced conservation strategies (Sangster et al. 2014). The taxonomic significance of the variation observed in the present study has to be assessed concerning the available taxonomic information on the species. Worldwide taxonomy of the Puntius including other Cyprinidae species has been dubious (Kortmulder 1972; Nagpure et al 2003; Kullander and Fang 2005; Balaraj and Basheer 2012; Sukham et al. 2015), and this has been the case for $S$. sarana in Asia. Hamilton in 1822 had described this species from the Ganga River and named Cyprinus sarana, and afterward, it was synonymies with Puntius sarana. Likewise, Puntius sarana have many synonyms assigned by various authors (Puntius sarana sarana, Puntius sarana subnasutus, Puntius sarana spilurus, Puntius subnasutus, Systomus immaculatus, Barbodes sarana, Barbodes sarana subnasutus, Puntius saberi, etc) these synonyms undoubtedly generate confusions in the identification of this species (Pethiyagoda 1991). So far five sub-species of $S$. sarana were identified worldwide; $P$. sarana orphoides, $P$. sarana subnasutus and $P$. sarana sarana from India and $P$. sarana spilurus from Sri Lanka (Irfan and Gunawickrama 2011). S. sabnasutus is referred to as S. sarana, although very recently it is categorized as a different sub-species (Biswal et al. 2018). These subspecies further adding taxonomic complexity of this species. Due to a lack of proper systematic studies and having phenotypic resemblance among subspecies, Pethiyagoda (1991) has recommended extensive population studies on these species by accompanying intra-species/population delineation studies (Talwar and Jhingran 1991, Irfan and Gunawickrama 2011).

Our organism of interest, Systomus sarana belong to the subfamily Barbinae, is a taxonomically diverse and complicated group of freshwater fish for studying morphological differences due to their wide distribution (Talwar and Jhingran 1991) and flipping systematic status i.e. many species formerly placed in Puntius have been moved to other genera (Kottelat 2013; Pethiyagoda et al. 2012; Raghavan et al. 2013). It is characterized by a deep and moderately compressed body with a dorsal profile elevated. The maximum length of fish is $42.0 \mathrm{~cm}$ TL (FishBase). Systomus sarana (then allocated to Puntius) is an ecologically important, profitable, and cultivable candidate fish species (Gopakumar et al. 1999; Chakraborty et al. 2003). In India, this species is distributed widely excluding peninsular India-south of Krishna River and is also found in Afghanistan, Bangladesh, Bhutan, Nepal, and Pakistan (Talwar and Jhingran 1991). Previous studies have indicated that it is abundantly available however recent reports 
and observations indicate a decline in their wild population owing to their overexploitation (Hossain et al. 2009; Dahanukar 2010; Hussain and Mazid 2004). consequently, considered as vulnerable species (Mijkherjee et al. 2002; Dahanukar 2010), some researchers also categorized them as critically endangered (Ameen et al. 2000; Hussain and Mazid 2004). Although unintentional selective fishing causing depletion of fish biodiversity hitherto, there is no published report on the fish population structure of $S$. sarana from Indian rivers based on morphometric characters. Moreover, only a little work has been done to delineate S. sarana population outside India (Irfan and Gunawickrama 2011; Siddik et al. 2016; Kabir et al. 2015).

Considering the above context, this study aims to find the morphological divergence of $S$. sarana populations from Ganga (North), Godavari (South), Mahanadi (East), and Narmada (Central) based on morphometric measurements by utilizing the following toolkits, truss network system and geometric morphometrics. This allows quantitative analysis of morphological divergences and may provide insight into microevolution.

\section{Results}

\section{Landmark-based truss analysis}

After the allometric transformation, there was no significant correlation $(p>0.05)$ found between standardized truss measurements with the standard length (SL), indicating that the size effect had been effectively removed from the data. Hence, all the measurements were utilized for further calculations. Further, the morphometric characters did not differ significantly $(p>0.05)$ between both sexes, therefore the data for both sexes were pooled for all subsequent analyses. By applying ANOVA (one way) on 90 morphometric characters, only 63 showed a significant difference in their mean values $(p<0.05)$. Paired post-hoc comparisons (Tukey's HSD) to investigate differences among populations revealed that all the 63 morphometric characters grouped four populations in a minimum of two and maximum four groups significantly $(p<0.05)$. Significant variables were subjected to PCA and DFA. PCA plot does not allow one to draw a conclusion about homogenous grouping based on visuals. By applying PCA, a total of 13 principal components were extracted explaining $93.31 \%$ of the total variance among populations. Principal component 1 (PC1) and PC2 contribute $24.41 \%$ and $19.03 \%$ of total variance respectively (Table 1). The high component loadings were on the characters $1-11,1-12,11-14,6-12.2-11,6-11,2-11,12-14$, $12-13,11-13,2-12,1-13,13-14,6-13$ to the first principal component, characters $4-13,2-4,3-4,1-4,4-14,4-$ $12,4-6$, and $4-11$ to the second and characters $1-5,5-14,5-13,2-5,3-5,5-12,5-11,5-8$ and $5-9$ to the third component. The factor analysis extracted 6 factors having eigenvalues summed to $\otimes 1$. The results of factor analysis indicated that the first three factors together explained $89.6 \%$ of the total morphometric variation, with eigenvalues of $58.1 \%, 28.8 \%$, and $13.1 \%$, respectively. Mahalanobis distances between the centroids of the clusters and the $p$-value of discriminant truss morphometric characters among four populations have been presented in Table 2. 
The Wilks' $k$ test revealed significant differences in morphometric characters among four populations ( $p>$ 0.001). Forward stepwise discriminant analysis of all the significant variables produced thirteen discriminating variables (Table 3). These variables or morphometric truss measurements were found to be the most important characters in distinguishing the selected populations. The linear discriminant analysis produced an average percentage correct classification (PCC) of $90.3 \%$ for morphometric characters indicating a high rate of correct classification of individuals into their original populations (Table 4). The percentage of correct classification ranged from $86.1 \%$ (Godavari) to $93.9 \%$ (Narmada). It was highest for the population of the River Narmada followed by River Mahanadi (92.9\%), River Ganga (86.2 \%), and lowest for River Godavari (86.1\%). The results attained from the PCC cross-validation test were analogous to the results. Additionally, the plot of the discriminant variables showed a pattern that reflects successful discrimination among populations of four rivers (Fig. 1).

\section{Landmark-based geometric morphometric analysis}

Shape coordinates were superimposed to successfully eliminate the size effect, which was apparent from Procrustes analysis (Procrustes sums of squares: 0.363 and Tangent sums of squares: 0.361 ). Also, partial least square (PLS) revealed a non-significant covariance between superimposed shape and log centroid size $(R=0.54 ; P>0.001)$, resulting in overlap among populations (Fig. 2). The deformed wireframe of average shape also showed variations between populations (Fig. 3). Visual examination of the body shape variation of these selected populations through wireframe diagrams revealed that they differ as follows; Shape variation in the anterior body depth profile was evident between Ganga (broad) and Godavari (slender) River populations. Shape variation in the anterior body depth profile was also noticed between populations of Godavari (slender) and Narmada (broad) River, Godavari (slender), and Mahanadi (broad) River, and Mahanadi (slender) and Narmada (broad) River. Ganga River population showed slender body profile at the anterior region and broad body profile in the middle region when compared to Narmada River populations while variation in depth in the middle body profile was noticed in Ganga (slender) and Mahanadi (broad) River populations. Relative warp (RW) analysis illustrated deformation in shape (Fig. 4) from the reference that corresponds to selected positions in the ordination. The deformed wireframe was drawn on the shape among four populations to interpret shape changes that support the RW analysis.

The PCA extracted 24 components with a $100.00 \%$ variance. The first two principal components (PCs) account for $40.22 \%$ of the total variance (22.48\% for $\mathrm{PC} 1,17.74 \%$ for $\mathrm{PC} 2$ ). Overlap among the specimens obtained from four rivers is evident in the PCA plot of PC1 and PC2 (Fig. 5). A low level of variance and a high level of overlapping in the PCA demands further verification through CVA and DFA to determine shape variations. The CVA based upon 14 landmarks showed four groups with slight overlap among populations (Fig. 6). The larger part (82.98\%) of the total variance $(100.00 \%)$ was explained along the first two canonical variates (CVs): CV1 and CV2 explained $55.47 \%$ and $27.50 \%$ of the total variance, respectively, while CV3 explained only $17.016 \%$ of the total variance. CVA extracted Mahalanobis and Procrustes distances among four groups found to be highly significant $(p<0.0001)($ Tables 5,6$)$. Classification results of CVA indicated that all the specimens of each group were allotted to their 
respective groups with a slight misclassification rate. The classification of individuals into their crossvalidated groups showed a low level of mixing between the populations (Table 7; Fig. 7). These results go well together with those depicted by the deformed wireframe of average shape.

\section{Discussion}

Several statistical methods have been employed to study morphological divergences among wild populations of $S$. sarana collected from different geographic regimes. This is the first study on the population discrimination of $S$. sarana using truss network analysis with geometric morphometrics. The results revealed that heterogeneity exists among examined populations of $S$. sarana procured from the specific sites of geographically isolated rivers (Ganga, Godavari, Narmada, and Mahanadi). Significant variations were detected for most of the analyses. The PCA loadings (truss analysis) of principal components revealed distinctness between populations. Though, there was a slight overlap found in the characters which were examined among the four groups. This separation was corroborated by DFA (truss analysis), showed significant morphological heterogeneity among populations, the level of differentiation between most of them as evidenced by a slight overlap of statistical data on derived plots.

Using geometric morphometrics, the CVA plot obtained, has shown a slight level of overlaps among groups with a high percentage of correct classification suggesting differentiation among the examined populations. The PCA (geometric analysis) and DFA (geometric analysis) further confirmed the morphological heterogeneity among populations of $S$. sarana. The higher misclassification (DFA) observed for the Ganga with Mahanadi River and least with the Narmada. The biological variations in morphometric characters based on DFA are majorly associated with head morphology, covering lateral body lengths and caudal peduncle regions. Shape differences have been visualized with the deformation grids using geometric morphometrics. Geometric morphometry-based deformation grids (wireframes and relative warps) of average shapes between populations correspond to the high values of statistical distance between them and confirm the distinctness of populations in their immediate anatomical context.

Overall, the variations among the four groups in this study were largely owing to the dissimilarities of morphometric characters broadly associated to head, and body characteristics. However, the shape differences observed in this study presents little practical use in terms of discriminating fish populations in the field. The visualization of the body shape differences, associated with other groups of correlated morphological traits, allowed to obtain a clear diagnosis of fish morphology for each population [43, 44]. Visualization tools might help in further study of the putative underlying mechanisms involved [45]. The result of the present study is in line with other studies based on truss analysis $[4,46-49]$ and geometric morphometrics $[50,51]$ which have shown the fish species to have a distinctive morphology.

Lotic ecosystems such as rivers exhibit distinctive spatial and temporal characteristics [52]. The biogeographical patterns of rivers have been determined by specific spatial features which are enclosed in geomorphology of drainage, the structure, and directional connectivity of the dendritic network, 
elevation area, the flow of water, flow duration, physicochemical milieu, and other abiotic/biotic factors and their interaction $[53,54]$. These factors possibly have a role in controlling morphologies of the fish fauna thriving in a particular aquatic environment $[55,56]$. The environmental characteristics of the present rivers (Ganga, Godavari, Narmada and Mahanadi) are quite remarkable. The snow-fed Ganga River is young, longer and deeper, perennial in nature, having a good amount of flow throughout the year, exhibiting a vigorous tendency of meandering has its origin from Himalaya while Godavari, Mahanadi and Narmada are rain-fed older Peninsular Rivers, originates from a small plateau, flows straight path, shallower basins, forming broad largely graded shallow valleys, and are characterized by fixed course and absence of meanders. The Narmada River can be further distinguished as being the west-flowing rivers of the peninsular plateau [57-60]. Further peninsular rivers, Godavari, Mahanadi and Narmada are also geographically isolated from each other. Godavari basin is disconnected from the Mahanadi basin by the Bastar hills and the Parasgaon plateau towards the basin's northern regions. Narmada basin is detached by the Maikala range from the Mahanadi basin in the east and Mahadeo hills in the south isolates the Narmada river basin from the Godavari basin [61].

The different environments often considered as a basis of strong divergent selection in morphological traits in the fish population. There is a relationship between morphological traits and their functions in connection with the environment $[62,63]$. Spatial isolation has led to high levels of morphological variability between populations. The highest percentage of correct classification for the Narmada River population indicates greater distinction from the other populations. These morphological changes correspond to variations in spatial and/or temporal features. As mentioned above, the selected populations were geographically isolated from each other which could have hindered the movement of fish from intermingling with populations in other rivers. Therefore, the variability in morphological characters among populations possibly accredited due to separate geographical locations, the microclimate of rivers, the distance between the rivers, as well as the environmental variability of the river experienced by each population which leads to the local adaptations [64, 65]. The morphological variation could probably be coupled with the variation of feeding regimes and above-mentioned habitat circumstances $[46,55,56,66-68]$. Additionally, different reports indicate variations of the whole fish body are mainly due to fish inhibiting in different flow regimes $[56,69]$.

Successful efforts have been made to differentiate $S$. sarana populations using traditional morphometrics [42] and genetics [41] from a neighbor country, Bangladesh which is far smaller in geography when compared to India. Therefore, in a geographically vast country like India having a number of isolated rivers, there is more possibility of variations among fish populations, which can be clearly depicted in the present study. The present study is in agreement with previous studies conducted with the same objective of detecting intraspecies morphological differences in other cyprinids [69-72] and non-cyprinids $[49,73,74]$ Though, there are also reports on low morphometric divergences despite of geographically isolated populations [75]. Hence, patterns of morphological structure in fishes differed between river basins/rivers/river stretches. Variations in the degree and pattern of morphological traits correspond to numerical values may depends on the species of fish examined or/and the 
method/methods utilized for examine the morphological variations thus the reasons of low divergence could be many which is subject of detailed investigation.

Morphological differentiation can enable individuals to survive with existing environmental variability [76]. Fishes are excellent model systems for studies on inter as well as intraspecific divergences to understand ecological correlates of morphological diversifications. Some factors were assumed to be controlling the differences observed such as plasticity owing to habitat dissimilarities or could be due to environment and genotype interactions. Earlier, it was assumed that the variation of morphometric characters was exclusively genetic but recent studies have established its relation with environmental factors [77-79] and the role of epigenetics cannot be ruled out as suggested by many scientists, population differentiation associated with ecological factors have the main element as epigenetic [80].

As mentioned above, intraspecific variability can have huge ecological effects [81-83]. Charles Darwin indicated that variations among individuals of species offer the raw materials for natural selection. All hereditary characters in the genotype are not expressed in the phenotype. Further, variation not attributable to genetic factors not necessarily is environmental. Interestingly, the environment is often made responsible for non-genetic variations in phenotypes but it could be because of meta-stable epigenetic regulation [84]. Considering that morphological variations are raw materials, truss and geometric analysis techniques are the best approaches to discriminate populations on the basis of morphological characters. Results from the present study show that geometric morphometrics can provide additional information for shape delineation between populations that might otherwise be unnoticed. Further, the use of both truss and geometric morphometrics can provide deeper insight into the pattern of shape variations. This study could not answer whether are the results of morphological plasticity, genetic difference, or interaction of either mechanisms or epigenetic related hence, to resolve this, additional studies such as common garden experiments and epigenetic and/or genetics studies can be performed. More precise results might be obtained if larger sample sizes with a greater geographical extent were available. Geometric morphometrics analyses that include other aspects of fish morphology could enhance the precision of results.

\section{Conclusion}

To summarize, we quantified the morphological variation among wild populations of $S$. sarana from four major rivers of India. The basic characteristics of discrimination are overall body shape majorly associated with head morphology, covering lateral body lengths and caudal peduncle regions. Body morphology shows variation and could separate most populations, observed morphological variations provide good evidence for intraspecies heterogeneity between $S$. sarana populations. The study suggests that the $S$. sarana distributed across selected Indian rivers shows morphological plasticity. The high degree of classification accuracy of these two approaches advocates their extension to other problematic species and highlights their importance as exploratory tools in morphological based population studies.

\section{Materials \& Methods}




\section{Study area}

For the present study, four rivers have been selected viz. Ganga (2600km), Narmada (1312km), Godavari $(1465 \mathrm{~km})$, and Mahanadi $(900 \mathrm{~km})$. The Ganga River originates in the Garhwal Himalayas from the Gaumukh glacier in Uttarakhand, India, and drains into the Sundarbans delta in the Bay of Bengal. The Narmada River originates from the Amarkantak, located in the Shahdol district of Madhya Pradesh, India and drains into the Arabian Sea. The Godavari River is also known as Dakshina Ganga, originating from the Nasik district of Maharashtra, India, and drained into the Bay of Bengal. The Mahanadi River, a major river in east-central India, originated Dandakaranya in Raipur district of Chhattisgarh, India empties itself into the Bay of Bengal. All the rivers taken into account are east flowing except the Narmada River, which is west-flowing.

\section{Sample collection}

A total of 154 specimens of $S$. sarana were collected from Azad nagar site of the River Ganga, Peddapalli site of River Godavari, Uda site of River Narmada, and Tribhona site of Mahanadi River in two years duration (2016 to 2018). The specimens were caught before the breeding season and after the spawning period to avoid the effect of gonadal maturation on possible morphological difference between populations. The fish samples were collected with the help of hired local fishermen. The identification of the fish was based on standard taxonomic keys of Talwar and Jhingaran [25] and Jayaram [85]. Detail information of sample collection and geographical coordinates of sites have been mentioned in Table 8. and Fig. 8.

\section{Digitization of samples and morphometric measurements}

The freshly caught sampled specimens (only undamaged) were placed with the left side up on a waterresistant paper and the body posture and fins were teased into a natural position to make the landmark points visible. Each individual was labeled with a specific code for identification and archiving purposes. Images of the specimens were taken by a camera (Canon IXUS145), set on a tripod stand directly above the specimen and the camera lens was adjusted and each image included a scale to normalize the individual sizes and additional scaling was applied in tpsDig making use of the millimeter gridiron in the graph paper.

\section{Landmark-based truss analysis}

Fourteen homologous anatomical landmarks [86] were selected for the analysis (Fig. 9). A box-truss network was developed to give 91 morphometric variables through interconnection among these landmarks. Software including tpsUtil, tpsDig [87], and software PAST [88] was employed for generating truss data from the digital images. Since the standard length (SL) of fish specimens were different, it was necessary to remove dissimilarities due to size variations [89]. The truss measurements were standardized to account for size variation through the method described by Elliott et al. [90] to eliminate the size component from the shape measurements: $M_{a d j}=M *(L s / L o)^{b}$, Where $M$ denotes original 
measurement, $M_{a d j}$ is the size-adjusted measurement, $L o$ is the $S L$ of the fish, and $L s$ is the overall mean SL for all fish from all samples in each analysis. Parameter $b$ was calculated for each character from the observed data as the slope of the regression of log M on log Lo. SL (character code 1-6) was excluded from the final analysis because SL was used as a basis for transformation [91] and thus 90 morphometric variables were retained for further analysis. The transformed data were validated for efficiency by testing the significance of the correlation between standard length and the transformed variables. The SL was excluded from the final analysis. Univariate ANOVA was performed for each morphometric character to assess the significant variation among the four populations [92]. Tukey's Honest Significant Difference (HSD) post-hoc pairwise test was performed for comparisons among populations, after adjusting $\mathrm{p}$ values with Bonferroni corrections. The transformed data representing characters that showed significant variation between populations were analyzed using PCA. This analysis was applied to determine the linear combinations of variables that responsible for a large amount of the variation in the data and to identify influential variables [93]. PCA plot was formed by using components that confirmed high variance. In PCA, Jolliffe's rule with eigenvalues of at least 0.7 was applied to retain principal components [94] and factor loading greater than 0.30 is considered significant, 0.40 more important, and 0.50 or greater very significant [95]. In the present study, only those factors were considered as significant that having loadings above 0.50 . The Wilks' $k$ was used to compare the differences. Further, a stepwise procedure was employed to lessen the number of variables to meet the requirement of a reduced set of characters for the DFA. Standardized canonical discriminant function coefficients and coefficients in the structure matrix were used as the criteria to identify the discriminating variables between two populations. DFA was used to assign individuals to their original group and to compute the percentage of correctly classified (PCC). Cross-validation (leave-one-out method) employing PCC was done to approximate the expected actual error rates of the classification functions. Statistical analyses were performed with the computer software programs MS-Excel (vers.2007), SPSS 16.0, and PAST 1.47.

\section{Landmark-based geometric morphometric analysis}

A geometric morphometric approach based on Procrustes methods has been used. To extract the body shape data employing the geometric morphometrics approach, 14 landmark-points were defined and digitized on the specimens' pictures using tpsDig2 software [96]. Two D X-Y coordinate data for 14 landmarks of all the 154 specimens were generated using software ImageJ version 1.50i (http://imagej.nih.gov/ij/) and saved in tps format. Landmarks were converted to shape coordinates by Procrustes superimposition [97], standardizing each specimen to unit centroid size, or an estimate of overall body size [98]. The covariation between shape and size was analyzed using Partial Least Square (PLS) analysis $[99,100]$. This method performs singular value decomposition on the matrix of covariances between two blocks of variables. Then, data were analyzed using relative warp (RW), which was carried out using TPSRELW [101]; http://life.bio.sunysb.edu/ee/rohlf/software.html) to produce and visualize the morphological variations. PCA was employed. The scores on the first four principal components were then used in a CVA to verify how well these could be used to discriminate amongst the 
populations. CVA was performed to assess the shape variations among the populations. CVA is a method of finding the set of axes that allows for the greatest possible ability to discriminate between two or more groups [102]. All statistical analyses were carried out with the software MorphoJ, version 1.06d [103]; http://www.flywings.org.uk/MorphoJ_page.htm) and Excel (Microsoft Office, 2007).

\section{Declarations}

Ethics approval and consent to participate Fish specimens were obtained from the wild, directly from the commercial catches. The collection sites of fish specimens collected were fell outside Protected Areas (PAs). Fish were captured by gill nets. Fish if alive were euthanized with MS222 (Sigma) anesthesia and transported to the laboratory on ice to avoid damage to its morphological characters. The Research Ethics Committee of the University of Lucknow, Uttar Pradesh, India has permitted the design and implementation. Systomus sarana is not considered a protected or endangered species in India and no special permits were required for handling and studying this fish species. All persons occupied in the capture, handling, holding, and processing of fish were aptly trained for their specific tasks during the procedure. All applicable international, national, and departmental guidelines for the care and use of animals were followed.

Consent for publication not applicable

Availability of data and materials The datasets used and/or analysed during the current study are available from the corresponding author on reasonable request.

Competing interests The authors declare that they have no competing interests

Funding This study was supported by University Grant Commission- BSR Fellowship to first author (251/2014-15(BSR)/7-109/2007/(BSR) Dated 25 August, 2015)

Authors' contributions D.G. initiated the research, and together with M.T. and A.K.D. outlined the study. D.G. collected the samples and performed all preliminary analysis, investigation, methodology. M.T. provided guidance, done project administration and supervised the study. D.G. and A.K.D. assisted with data curation, software, validation, visualization. D.G. wrote the original draft of the manuscript, revised and rewrote it. D.G., A.K.D. and M.T. reviewed and edited the manuscript.

Acknowledgements Authors are grateful to Head, Department of Zoology, Lucknow University, Lucknow, India for providing necessary laboratory facilities. The authors are also thankful to local fishermen for assistance with sample collection.

\section{References}


1. Ihssen PE, Booke HE, Casselman JM, McGlade JM, Payn NR, Utter EM. Stock identification: materials and methods. Can J Fish Aquat Sci. 1981;38:1838-55.

2. Petrtyl $M$, Kalous $L$, Memiş $D$. Comparison of manual measurements and computer-assisted image analysis in fish morphometry. Turk J Vet Anim Sci. 2014;38:88-94. https://doi:10.3906/vet-1209-9

3. Yusuf B, Belduz AO. Morphological Variation among Atlantic Horse Mackerel, Trachurus trachurus Populations from Turkish Coastal Waters. Turk J Vet Anim. Sci. 2009;8:511-517.

4. Dwivedi AK. Morphometric variations between seasonal migrants of anadromous shad Tenualosa ilisha (Hamilton, 1822) from Hooghly Estuary, India. Mar Freshwater Res. 2019;70:1427https://doi:org/10.1071/MF19004

5. Clayton JW. The stock concept and the uncoupling of organismal and molecular evolution. Can J Fish Aquat Sci. 1981;38:1515-1522.

6. AnvariFar H, Khyabani A, Farahmand H, Vatandoust S, AnvariFar H, Jahageerdar S. Detection of morphometric differentiation between isolated up- and downstream populations of Siah Mahi (Capoeta capoeta gracilis) (Pisces: Cyprinidae) in the Tajan River (Iran). Hydrobiologia. 2011;673: 41-52. https://doi.org/10. 1007/s10750-011-0748-7

7. Turan C. A note on the examination of morphometric differentiation among fish populations: the truss system. Turk J Zool. 1999;23:259-263.

8. Takács P, Vitál Z, Ferincz Á, Staszny Á. Repeatability, Reproducibility, Separative Power and Subjectivity of Different Fish Morphometric Analysis Methods. PlosOne. 2016;11, e0157890. https://doi.org/10.1371/journal.pone.0157890

9. Strauss RE, Bookstein FL. The truss: body form reconstructions in morphometrics. Syst Biol.1982;31:113-135.

10. Rohlf FJ. Morphometrics. Annu Rev Ecol Syst. 1990;21:299-316.

11. Bookstein FL. Morphometric Tools for Landmark Data: Geometry and Biology. Cambridge University Press; 1991.

12. Rohlf FJ, Marcus LF. A revolution in morphometrics. Trends Ecol Evol. 1993;8:129-132. https://doi:10.1371/journal.pone.0157890

13. Gupta D, Dwivedi AK, Tripathi M. Taxonomic validation of five fish species of subfamily Barbinae from the Ganga river system of northern India using traditional and truss analyses. PLoS One, 2018;13:10 p. e0206031, 1371/journal.pone.0206031

14. Ishihara T. The Euler characteristics and Weyl's curvature invariants of submanifolds in spheres. J Math Soc Jpn. 1987;39:247-256. doi:10.2969/jmsj/03920247.

15. Sangster G, Luksenburg JA. Declining rates of species described per taxonomist: slowdown of progress or a side- effect of improved quality in taxonomy? Systematic Biology. 1987;64:144-151. doi.org/10. 1093/sysbio/syu069

16. Kortmulder K. A comparative study in colour patterns and behaviour in seven Asiatic Barbus species (Cyprinidae, Ostariophysi, Osteichthyes). A progress report. Behaviour, Leiden, EJ Brill. pp. III, V-XI, 1- 
(1972).

17. Nagpure NS, Kushwaha B, Srivastava SK, Kumar R, Gopalakrishnan A, Basheer VS, Verma MS. Characterization of endemic fish species from Western Ghats, Labeo dussumieri, Horabagrus brachysoma, and Puntius filamentosususing Cytogenetic markers. Nucleus. 2003;46:110-114.

18. Kullander SO, Fang F. Two new species of Puntiusfrom northern Myanmar (Teleostei: Cyprinidae). Copeia. 2005;2:290-302.

19. Balaraj S, Basheer M. Genetic diversity among Puntius sophorecomplex using restriction fragment length polymorphism. Journal of Medical and Allied Sciences. 2012;2:49-53.

20. Sukham S, Chingakham B, Thoidingjam L, Waikhom G, Kumar R, Kushwaha B. Cytogenetic characterization of Pethia meingangbii(Arunkumar and Tombi, 2003) (Cypriniformes: Cyprinidae): karyotypic evolutionary and taxonomic perspectives. International Journal of Research in Fisheries and Aquaculture. 2015;5:156-162.

21. Pethiyagoda R. Freshwater fishes of Sri Lanka. Wildlife Heritage Trust of Sri Lanka, Colombo 8, 362 pp. 1991.

22. Irfan Fl, Gunawickrama KBS. Osteological variation of the olive barb Puntius sarana (Cyprinidae) in Sri Lanka. J Natl Sci Found Sri. 2011;39:121-128.

23. Biswal JR, Singh RK, Lal KK, Mohindra V, Kumar R, Kumar RG. Basheer VS, Jena JK. Molecular and morphological evidences resolve taxonomic ambiguity between Systomus sarana sarana (Hamilton, 1822) and sarana subnasutus (Valenciennes) and suggest elevating them into distinct species. Mitochondrial DNA Part B. 2018;3:838-844. doi: 10.1080/23802359.2018.1481775

24. Sudasinghe H, Pethiyagoda R, Raghavan R, Dahanukar N, Rüber L, Meegaskumbura M. Diversity, phylogeny and biogeography of Systomus (Teleostei, Cyprinidae) in Sri Lanka. Zool Scr. 2020;00:122. https://doi.org/10.1111/zsc. 12445

25. Talwar PK, Jhingran AG. Inland Fishes of India and Adjacent Countries. Oxford-IBH Publishing Co. Pvt. Ltd., New Delhi, 1158 p. (1991)

26. Dahanukar N. Systomus sarana subnasutus. The IUCN Red List of Threatened Species 2013: e.T172514A6907469. 2013. http://dx.doi.org/10. 2305/IUCN.UK.2011-1.RLTS.T172514A6907469.en

27. Coyne JA, Orr HA. Speciation. Vol. 37 (Sinauer Associates Sunderland, MA) (2004).

28. Rundle HD, Schluter D. Natural Selection and Ecological Speciation in Sticklebacks. In: Adaptive Speciation, eds. Dieckmann U, Doebeli M, Metz JAJ \& Tautz D, pp. 192-209. Cambridge University Press. (2004)

29. Pethiyagoda R, Meegaskumbura M, Maduwage KA. synopsis of the South Asian fishes referred to Puntius (Pisces: Cyprinidae). Ichthyol Explor Freshw. 2012;23:69-95.

30. Kottelat M. The Fishes of the Inland Waters of Southeast Asia: A Catalogue and Core Bibliography of the Fishes Known to Occur in Freshwaters, Mangroves and Estuaries. Raffles Bull Zool. 2013; Supplement No. 27:1-663. 
31. Raghavan R, Dahanukar N, Tlusty MF, Rhyne AL, Kumar KK, Molur S, Rosser AM. Uncovering an obscure trade: threatened freshwater fishes and the aquarium pet markets. Biol Conserv. 2013;164:158-169. https://doi.org/10.1016/j.biocon.2013.04.019

32. Gopakumar K, Ayyappan S, Jena JK, Sahoo SK, Sarkar SK, Satapathy BB, Nayak PK. In: National Freshwater Aquaculture Development Plan. Central Institute of Freshwater Aquaculture, Bhubaneswar, India. 75 pp. 1999

33. Chakraborty BK, Miah MI, Mirza MJA, Habib MAB. Rearing and nursing of local Sarpunti, Puntius sarana, (Hamilton) at different stocking densities. Pak J Biol Sci. 2003;6:797-800. http://dx.doi.org/10.3923/pjbs.2003.797.800

34. Sidthimunka A. A report on the fisheries survey of the Mekong River in the vicinity of the Pa Mong Dam site. Inland Fisheries Division, Department of Fisheries, Bangkok, Thailand. 75 p. (1970)

35. Oo W. Inland fisheries of the Union of Myanmar. In T. Petr, and D. B. Swar, editors. Cold water fisheries in the Trans-Himalayan countries. Technical Paper 431, FAO Fisheries. 2002.

36. Hussain MG, Mazid MA. Carp genetic resources of Bangladesh. In: Penman D, Gupta MV, Dey M (Eds.), Carp Genetic Resources for Aquaculture in Asia. World Fish Center, Penang. (2004)

37. Hossain MY, Ohtomi J, Ahmed ZF. Morphometric, meristic characteristics and conservation of the threatened fish, Puntius sarana (Hamilton, 1822) (Cyprinidae) in the Ganges River, northwestern Bangladesh. Turk J Fish Aquat Sc. 2009;9:223-225. http://doi: 10.4194/trjfas.2009.0215

38. Dahanukar N. Systomus sarana. The IUCN Red List of Threatened Species 2010: doi.org/10.2305/IUCN.UK.20104.RLTS.T166567A6237905.en. Accessed 27 June 2018.

39. Mijkherjee M, Praharaj A, Das S. Conservation of endangered fish stocks through artificial propagation and larval rearing technique in West Bengal, India. Aquacul Asia. 2002;7(2):8-11.

40. Ameen M, Islam MA, Nishat A. Red Book of Threatened Fishes of Bangladesh. IUCN The World Conservation Union, pp. 116. (2000)

41. Kabir A, Habib MA, Hossain A, Mandal SC. Genetic diversity of olive barb (Systomus sarana, Hamilton, 1822) from different locations of Bangladesh. Croat J Fish. 2015;73:6-12. http://dx.doi.org/10.14798/73.1.776

42. Siddik MAB, Chaklader MR, Hanif MA, Islam MA, Sharker MR, Rahman M. Stock identification of critically endangered olive barb, Puntius sarana (Hamilton, 1822) with emphasis on management implications. J Aquac Res 2016;7:411. http://doi: 10.4172/2155-9546.1000411

43. Viscosi V, Cardini A. Leaf Morphology, Taxonomy and Geometric Morphometrics: A simplified protocol for beginners. PLoS One. 2011;6:e25630. doi:10.1371/journal.pone.0025630

44. Orlofske JM, Baird DJ. A geometric morphometric approach to establish body-shape trait criteria for aquatic insects. Freshw Sci. 2014;33:978-994.

45. Manacorda CA, Asurmendi S. Arabidopsis phenotyping through geometric morphometrics. 2018;7:120. 
46. Khan MA, Miyan K, Khan S. Morphometric variation of snakehead fish, Channa punctatus, populations from three rivers. J Appl Ichthyol. 2012;28:154-155. https://doi.org/10.1111/j.14390426.2012.02058.x

47. Mohaddasi M, Shabanipour N, Abdolmaleki S. Morphometric variation among four populations of Shemaya (Alburnus chalcoides) in the south of Caspian Sea using truss network. J Basic Appl Zool. 2013a;66:87-92. https://doi.org/10.1016/j.jobaz.2013.09.001

48. Mohaddasi M, Shabanipour N, Eagderi S, Yazdi. A Habitat-associated morphological divergence in four Shemaya, Alburnus chalcoides (Actinopterygii: Cyprinidae) populations in the southern Caspian Sea using geometrics analysis. Int J Aquat Biol. 2013b;1:82-92.

49. Hanif MA, Chaklader MR, Siddik MAB, Nahar A, Foysal MJ, Kleindienst R. Morphological variation of gizzard shad, Anodontostoma chacunda (Hamilton, 1822) based on truss network model. Regional Stud Mar Sci. 2019;25:100442. https://doi.org/10.1016/j.rsma.2018.100442

50. Geladakis G, Nikolioudakis N, Koumoundouros G, Somarakis S. Morphometric discrimination of pelagic fish stocks challenged by variation in body condition. ICES J Mar Sci. 2018;75:711-718. https://doi.org/10.1093/icesjms/fsx186

51. Pérez-Quiñonez Cl, Quiñonez-Velázquez C, García Rodríguez FJ. Detecting Opisthonema libertate (Günther, 1867) morphological stocks in northwestern coast of Mexico using geometric morphometrics based on body and otolith shape, Lat Am J Aqua Res. 2018;46:779-790. http://dx.doi.org/10.3856/vol46-issue4-fulltext-15

52. Read DS, Gweon HS, Bowes MJ, Newbold LK, Field D, Bailey MJ, Griffiths RI. Catchment-scale biogeography of riverine bacterioplankton. ISME J. 2014;9:516-526. 10.1038/ismej.2014.166

53. Zogaris S, Economou AN. The Biogeographic Characteristics of the River Basins of Greece, The Rivers of Greece: Evolution, Current Status and Perspectives, Hdb Env Chem. 2017 DOI 10.1007/698_2017_475

54. Denney DA, Jameel MI, Bemmels JB, Rochford ME, Anderson JT. Small spaces, big impacts: contributions of micro-environmental variation to population persistence under climate change. AoB Plants. 2020;12:plaa005; doi: 10.1093/aobpla/plaa005

55. Lostrom S, Evans JP, Grierson PF, Collin SP, Davies PM, Kelley JL. Linking stream ecology with morphological variability in a native freshwater fish from semi- arid Australia. Ecol Evol. 2015;5:3272-3287. doi: 10.1002/ece3.1590

56. Jearranaiprepame P. Morphological differentiation among isolated populations of dwarf snakehead fish, Channa gachua (Hamilton, 1822) using truss network analysis. Acta Biol Szeged. 2017;61: 119-128.

57. Gupta H, Chakrapani GJ. Temporal and spatial variations in water flow and sediment load in Narmada River Basin, India: natural and man-made factors. Environ Geol. 2005;48:579-589. https://doi.org/10.1007/s00254-005-1314-2

58. Gupta N, Pandey P, Hussain J. Effect of physicochemical and biological parameters on the quality of river water of Narmada, Madhya Pradesh, India, Water Sci. 2017;31(1):11-23. DOI: 
10.1016/j.wsj.2017.03.002

59. Bhutekar D, Aher SB, Babare M. Spatial and Seasonal Variation in Physico-Chemical Properties of Godavari River Water at Ambad Region, Maharashtra. 2018;32:15-23.

60. Maurya P, Malik DS, Yadav KK, Kumar A, Kumar S, Kamyab H. Bioaccumulation and potential sources of heavy metal contamination in fish species in River Ganga basin: Possible human health risks evaluation. Toxicol Rep. 2019;6. 10.1016/j.toxrep.2019.05.012.

61. Hussain J, Husain I, Arif M, Gupta N. Studies on heavy metal contamination in Godavari river basin. Appl Water Sci. 2017;7:4539-4548. https://doi.org/10.1007/s13201-017-0607-4

62. Vega-Trejo R, Zúñiga-Vega JJ, Langerhans RB. Morphological differentiation among populations of Rhinella marina(Amphibia: Anura) in western Mexico. Evol Ecol. 2014;28:69-88. https://doi.org/10.1007/s10682-013-9667-6

63. Higham TE, Rogers SM, Langerhans RB, Jamniczky HA, Lauder GV, Stewart WJ, Martin CH, Reznick DN. Speciation through the lens of biomechanics: locomotion, prey capture and reproductive isolation. Proc R Soc B. 2016;283:20161294. http://dx.doi.org/10.1098/rspb.2016.1294

64. Paugy D, Lévêque C Taxinomie et systématique. In: Lévêque C, Paugy D (eds) Les poissons des eauxcontinentalesafricaines. Diversité, écologie et utilisation par l’homme. IRD, Paris, pp 97-119. (1999)

65. Pardo R. Morphologic differentiation of Trichomycterus areolatusValenciennes 1846 (Pisces: Siluriformes: Trichomycteridae) From Chile. 2002;66:203-205. https://doi.org/10.4067/S071765382002000200015

66. Langerhans RB, Gifford ME, Joseph EO. Ecological speciation in Gambusia Evolution. 2007;61:2056-2074.

67. Sajina AM, Chakraborty SK, Jaiswar AK, Pazhayamadam DG, Deepa S. Stock structure analysis of Megalaspis cordyla (Linnaeus, 1758) along the Indian coast based on truss network analysis. Fish Res. 2011;108:100-105.

68. Drinan TJ, McGinnity P, Coughlan JP, Cross TF, Harrison SCS. Morphological variability of Atlantic salmon Salmo salarand brown trout Salmo trutta in different river environments. Ecol Freshw Fish. 2012;21:420-432. doi:org/10.1111/j.1600-0633.2012.00561.x

69. Shukla R, Bhat A. Morphological divergences and ecological correlates among wild populations of zebrafish (Danio rerio). Environ Biol Fishes. 2017;100:251-264. https://doi.org/10.1007/s10641-0170576-3

70. Mir JI, Sarkar UK, Dwivedi AK, Gusain OP, Jena JK. Stock structure analysis of Labeo rohita (Hamilton, 1822) across the Ganga basin (India) using a truss network system. J Appl Ichthyol. 2013;29:1097-1103. https://doi: 10.1111/jai.12141

71. Jalili P, Eagderi S, Keivany Y. Body shape comparison of Kura bleak (Alburnus filippii) in Aras and Ahar-Chai rivers using geometric morphometric approach. Research in Zoology. 2015;5(1):20-24. doi: 10.5923/j.zoology.20150501.03 
72. Panda A, Jena D, Datta M, PJanmejay, K Radhakrishnan, Pandey P. Morphological and molecular divergence of Indian hill trout, Barilius bendelisis (Hamilton, 1822) stocks from different Rivers in Indo-Burma biodiversity hotspot: Does river altitude and Dam play a role?. J Appl Ichthyol. 2019;00:1-7. DOI: 10.1111/jai.13978

73. Colihueque N, Corrales $\mathrm{O}$, Yáñez M. Morphological analysis of Trichomycterus areolatus Valenciennes, 1846 from southern Chilean rivers using a truss-based system (Siluriformes, Trichomycteridae). ZooKeys. 2017;695:135-152. https://doi.org/10.3897/zookeys.695.13360

74. Khan MA, Khan S, Miyan K. Stock identification of the Channa striatalnhabiting the Gangetic River System using Truss Morphometry. Russ J Ecol. 2019;50:391-396. https://doi.org/10.1134/S1067413619040106

75. Das P, Bej D, Swain S, Mishra CK, Sahoo L, Jena JK, Jayasankar P, Das P. Population divergence and structure of Cirrhinus mrigala from peninsular rivers of India, revealed by mitochondrial cytochrome b gene and truss morphometric analysis. Mitochondrial DNA. 2013;Early Online:1-8. https://doi: 10.3109/19401736.2013.792055. Epub 2013 Jun 24.

76. Senay C, Boisclair D, Peres-Neto PR. Habitat-based polymorphism is common in stream fishes. J Anim Ecol. 2015;84:219-227. https://doi.org/10.1111/1365-2656.12269

77. Georga I, Koumoundouros G. Thermally induced plasticity of body shape in adult zebrafish Danio rerio (Hamilton, 1822). J Morphol. 2010;271:1319-1327. https://doi.org/10.1002/jmor.10874

78. Nahar A, Siddik MAB, Alam MA, Chaklader MR. Population genetic structure of paradise threadfin Polynemus paradiseus(Linnaeus, 1758) revealed by allozyme marker. Int J Zool Res. 2015;11:48-56. http://dx.doi.org/10.3923/ijzr.2015.48.56

79. Sharker MR, Siddik MAB, Nahar AM, Shahjahan AA, Faroque. Genetic differentiation of wild and hatchery populations of Indian major carp Cirrhinus cirrhosis in Bangladesh. J Environ Biol. 2015;36:1223-1227.

80. Felsenfeld GA. Brief History of Epigenetics. Cold Spring Harb Perspect Biol. 2014;6:a018200. https://doi:10.1101/cshperspect.a018200

81. Fridley JD, Grime JP. Community and ecosystem effects of intraspecific genetic diversity in grassland microcosms of varying species diversity. Ecology. 2010;91:2272-2283. https://doi.org/10.1890/09-1240.1

82. Becks L, Ellner SP, Jones LE, Jr Hairston NG. Reduction of adaptive genetic diversity radically alters eco-evolutionary community dynamics. Ecol Lett. 2010;13:989-997. https://doi.org/10.1111/j.14610248.2010.01490.x

83. Bolnick DI, Amarasekare P, Araújo MS, Bürger R, Levine JM, Novak M, Rudolf VH, Schreiber SJ, Urban MC, Vasseur D Why intraspecific trait variation matters in community ecology. Trends Ecol Evol. 2011;26:183-192. https://doi.org/10.1016/j.tree.2011.01.009 (2011).

84. Wong AHC, Irving IG, Arturas P. Morphological differences in genetically identical organisms: the epigenetic perspective. Hum Mol Gen. 2005;1: R11-R18. https://doi.org/10.1093/hmg/ddi116 
85. Jayaram KC. The freshwater fishes of the Indian region (2nd ed.). Narendra Publishing House, Delhi. (2010).

86. Winans GA, Nishioka RS. A multivariate description of change in body shape of coho salmon (Oncorhynchus kisutch) during smoltification. Aquaculture. 1987;66:235-245. https://doi.org/10.1016/0044-8486(87)90109-8

87. Rohlf FJ. TPS Dig, Digitize Landmarks and Outlines, Version 2.05. Stony Brook, NY: Department of Ecology and Evolution, State University of New York. (2006)

88. Hammer $\varnothing$, Harper DAT, Ryan PD. PAST: Paleontological Statistics Software Package for Education and Data Analysis. Palaeontol Electron. 2001;4:1-9.

89. Reist JD. An empirical evaluation of several univariate methods that adjust for size variation in morphometric data. Can J Zool. 1985;63:1429-1439.

90. Elliott NG, Haskard K, Koslow JA. Morphometric analysis of orange roughy (Hoplostethus atlanticus) off the continental slope of southern. Australia J Fish Biol. 1995;46:202-20. https://doi.org/10.1111/j.1095-8649.1995.tb05962.x

91. Mamuris Z, Apostolidis AP, Panagiotaki $P$, Theodorou AJ, Triantaphyllidis C. Morphological variation between red mullet populations in Greece. J Fish Biol. 1998;52:107-117. https://doi.org/10.1111/j.1095-8649.1998.tb01556.x

92. Gomez-Rodriguez M, Leskovec J, Krause A. Inferring Networks of Diffusion and Influence. In KDD '10: Proceedings of the 16th ACM SIGKDD International Conference on Knowledge Discovery in Data Mining 1019-1028 pp. (2010)

93. Johnson RA, Wichern DW. Applied Multivariate Statistical Analysis, Fourth Edition, Prentice- Hall, New Jersey. 816 pp. (1998)

94. Dunteman GH. Principal component analysis. Sage Publications, Newbury Park, Calif. (1989)

95. Nimalathasan B. Profitability of listed pharmaceutical companies in Bangladesh: An inter and intra comparison of AMBEE and IBN SINA Companies Ltd, Economic and Administrative series. 2009;3:139-148.

96. Rohlf FJ. TPS Dig, version 2.04. State University of New York, Department of Ecology and Evolution, Stony Brook (2005)

97. Rohlf FJ, Slice D. Extensions of the Procrustes Method for the Optimal Superimposition of Landmarks. Syst Biol. 1990;39:40-59. https://doi:10.2307/2992207

98. Bookstein FL. Morphometric Tools for Landmark Data: Geometry and Biology. Cambridge Univeristy Press, 435 pp (1991)

99. Rohlf FJ, Corti M. Use of two- block partial least-squares to study covariation in shape. Syst Biol. 2000;49:740-753. https://doi.org/10.1080/106351500750049806

100. Zelditch ML, Swiderski DL, Sheets HD, Fink WL. Geometric morphometrics for biologists: a primer. London: Elsevier Academic Press;2004 
101. Rohlf FJ. Relative warps. In: Ecology and Evolution. State University of New York at Stony Brook, Stony Brook, New York;2010

102. Mardia KV, Kent JT, Bibby JM. Multivariate Analysis. Academic Press, London;1979 https://doi.org/10.1002/bimj.4710240520

103. Klingenberg CP. MorphoJ: an integrated software package for geometric morphometrics. Mol Ecol Resour. 2011;11:353- http://dx.doi.org/10.1111/j.1755-0998.2010.02924.x

\section{Tables}

Table 1. Eigenvalue, Percentage of variance, Cumulative percentage. Eigenvalues, percentages of variances, and cumulative percentages for the 13 principal components from a PCA in case of 63 morphometrics measurements from four populations of Systomus sarana.

\begin{tabular}{|c|c|c|c|}
\hline \multirow[t]{2}{*}{ Components } & \multicolumn{3}{|c|}{ Initial Eigenvalues } \\
\hline & Eigenvalue & Percentage of variance & Cumulative percentage \\
\hline 1 & 15.4 & 24.4 & 24.4 \\
\hline 2 & 12.0 & 19.0 & 43.4 \\
\hline 3 & 5.4 & 8.6 & 52.0 \\
\hline 4 & 5.0 & 7.9 & 60.0 \\
\hline 5 & 4.3 & 6.8 & 66.8 \\
\hline 6 & 3.6 & 5.7 & 72.5 \\
\hline 7 & 3.0 & 4.8 & 77.3 \\
\hline 8 & 2.2 & 3.5 & 80.7 \\
\hline 9 & 2.1 & 3.3 & 84.0 \\
\hline 10 & 1.8 & 2.8 & 86.9 \\
\hline 11 & 1.6 & 2.5 & 89.3 \\
\hline 12 & 1.5 & 2.4 & 91.7 \\
\hline 13 & 1.0 & 1.6 & 93.3 \\
\hline
\end{tabular}

Table 2. Mahalanobis distances based on truss morphometrics. Pair wise matrix of Mahalanobis distances between the centroids of the population clusters (above diagonal) and corresponding p-values (below diagonal) 
from DFA of discriminant 63 truss-based morphometric characters distances among four populations of Systomus sarana.

\begin{tabular}{|l|l|l|l|l|}
\hline Groups & Ganga & Godavari & Narmada & Mahanadi \\
\hline Ganga & & 30.41 & 37.22 & 18.90 \\
\hline Godavari & $<.0001$ & & 22.00 & 17.70 \\
\hline Narmada & $<.0001$ & $<.0001$ & & 36.90 \\
\hline Mahanadi & $<.0001$ & $<.0001$ & $<.0001$ & \\
\hline
\end{tabular}

Table 3. Summary of morphological features differentiating populations. Thirteen linear measurements were of major importance in the delineation of these populations. 


\begin{tabular}{|c|c|c|c|}
\hline $\begin{array}{l}\text { S. } \\
\text { No. }\end{array}$ & $\begin{array}{l}\text { Character } \\
\text { Code }\end{array}$ & Morphological Feature & Body part \\
\hline 1 & $1-2$ & $\begin{array}{l}\text { distance between anterior tip of snout at upper jaw to most posterior } \\
\text { aspect of neurocranium }\end{array}$ & Head length 1 \\
\hline 2 & $1-7$ & $\begin{array}{l}\text { distance between anterior tip of snout at upper jaw to anterior } \\
\text { attachment of ventral membrane from caudal fin }\end{array}$ & Body length \\
\hline 3 & $2-4$ & $\begin{array}{l}\text { distance between most posterior aspect of neurocranium to end of dorsal } \\
\text { fin }\end{array}$ & $\begin{array}{l}\text { Mid body } \\
\text { length } 1\end{array}$ \\
\hline 4 & $2-5$ & $\begin{array}{l}\text { distance between most posterior aspect of neurocranium to anterior } \\
\text { attachment of dorsal membrane from caudal fin }\end{array}$ & $\begin{array}{l}\text { Mid Body } \\
\text { length } 2\end{array}$ \\
\hline 5 & $2-10$ & $\begin{array}{l}\text { distance between most posterior aspect of neurocranium to insertion of } \\
\text { pelvic fin }\end{array}$ & $\begin{array}{l}\text { Max. Body } \\
\text { depth }\end{array}$ \\
\hline 6 & $2-11$ & $\begin{array}{l}\text { distance between most posterior aspect of neurocranium to insertion of } \\
\text { pectoral fin }\end{array}$ & Head depth \\
\hline 7 & $5-12$ & $\begin{array}{l}\text { distance between anterior attachment of dorsal membrane from caudal } \\
\text { fin to end of operculum }\end{array}$ & $\begin{array}{l}\text { Mid diagonal } \\
\text { length } 1\end{array}$ \\
\hline 8 & $5-14$ & $\begin{array}{l}\text { distance between anterior attachment of dorsal membrane from caudal } \\
\text { fin to anterior end of eye }\end{array}$ & $\begin{array}{l}\text { Mid diagonal } \\
\text { length } 2\end{array}$ \\
\hline 9 & $6-7$ & $\begin{array}{l}\text { distance between posterior end of vertebrae column to anterior } \\
\text { attachment of ventral membrane from caudal }\end{array}$ & $\begin{array}{l}\text { Half base of } \\
\text { caudal fin }\end{array}$ \\
\hline 10 & $6-8$ & distance between posterior end of vertebral column to end of anal fin & $\begin{array}{l}\text { Caudal } \\
\text { peduncle } \\
\text { length }\end{array}$ \\
\hline 11 & $7-14$ & $\begin{array}{l}\text { distance between anterior attachment of ventral membrane from caudal } \\
\text { fin to anterior end of eye }\end{array}$ & $\begin{array}{l}\text { Mid body } \\
\text { length } 3\end{array}$ \\
\hline 12 & $11-12$ & distance between insertion of pectoral fin to end of operculum & $\begin{array}{l}\text { Portion of } \\
\text { head depth }\end{array}$ \\
\hline 13 & $11-13$ & distance between insertion of pectoral fin to posterior end of eye & $\begin{array}{l}\text { Post orbital } \\
\text { length }\end{array}$ \\
\hline
\end{tabular}

Table 4. Discriminant function analysis based on truss morphometric. Discriminant function analysis of on 13 truss-based morphometric distances characters among in four populations $(90.3 \%$ of original grouped cases correctly classified and $83.8 \%$ of cross-validated grouped cases were correctly classified). 


\begin{tabular}{|c|c|c|c|c|c|c|}
\hline \multicolumn{7}{|c|}{ Predicted Group Membership } \\
\hline \multirow[b]{5}{*}{ Original percentage (\%) } & Species & Ganga & Godavari & Narmada & Mahanadi & Total \\
\hline & Ganga & 86.2 & 3.4 & 3.4 & 6.9 & 100.0 \\
\hline & Godavari & 2.8 & 86.1 & 5.6 & 5.6 & 100.0 \\
\hline & Narmada & 3.0 & 3.0 & 93.9 & .0 & 100.0 \\
\hline & Mahanadi & 3.6 & 1.8 & 1,8 & 92.9 & 100.0 \\
\hline \multirow[b]{4}{*}{ Cross validated percentage (\%) } & Ganga & 72.4 & 6.9 & 3.4 & 17.2 & 100.0 \\
\hline & Godavari & 2.8 & 80.6 & 8.3 & 8.3 & 100.0 \\
\hline & Narmada & 3.0 & 6.1 & 90.9 & .0 & 100.0 \\
\hline & Mahanadi & 7.1 & 3.6 & 1.8 & 87.5 & 100.0 \\
\hline
\end{tabular}

Table 5. Mahalanobis distances based on geometric morphometrics. Pair wise matrix of Mahalanobis distances among groups (upper diagonal) and $p$ value (lower diagonal) of canonical variate analysis.

\begin{tabular}{|c|c|c|c|c|}
\hline Groups & Ganga & Godavari & Narmada & Mahanadi \\
\hline Ganga & & 5.8149 & 4.0786 & 3.9214 \\
\hline Godavari & $<.0001$ & & 4.1109 & 4.5639 \\
\hline Narmada & $<.0001$ & $<.0001$ & & 3.3623 \\
\hline Mahanadi & $<.0001$ & $<.0001$ & $<.0001$ & \\
\hline
\end{tabular}

Table 6. Procrustes distances based on geometric morphometrics. Pair wise matrix of Procrustes distances among groups (upper diagonal) and $p$ value (lower diagonal) of canonical variate analysis.

\begin{tabular}{|c|c|c|c|c|}
\hline Groups & Ganga & Godavari & Narmada & Mahanadi \\
\hline Ganga & & 0.0357 & 0.0272 & 0.0269 \\
\hline Godavari & $<.0001$ & & 0.0241 & 0.0265 \\
\hline Narmada & $<.0001$ & $<.0001$ & & 0.0189 \\
\hline Mahanadi & $<.0001$ & $<.0001$ & $<.0001$ & \\
\hline
\end{tabular}


Table 7. Discriminant function analysis based on geometric morphometric. Misclassification of specimens between groups extracted from discriminant function analysis.

\begin{tabular}{|l|l|l|l|l|l|}
\hline Classification & Groups & Ganga & Godavari & Mahanadi & Narmada \\
\hline Validated & Ganga & & 0 & 2 & 0 \\
\hline & Godavari & 0 & & 1 & 0 \\
\hline & Mahanadi & 1 & 1 & & 0 \\
\hline & Narmada & 0 & 0 & 0 & \\
\hline Validated & Ganga & & 1 & 6 & 4 \\
\hline & Godavari & 4 & & 4 & 2 \\
\hline & Mahanadi & 3 & 4 & & 4 \\
\hline & Narmada & 3 & 1 & 3 & \\
\hline
\end{tabular}

Table 8. Samples collection details. Localities, GPS location, sample size and size statistics of Systomus sarana captured from the sampling sites of selected Indian rivers.

\begin{tabular}{|c|c|c|c|c|c|c|c|}
\hline \multirow[t]{2}{*}{ River } & \multirow[t]{2}{*}{ Location } & \multirow[t]{2}{*}{ State } & \multicolumn{2}{|c|}{ GPS location } & \multirow{2}{*}{$\begin{array}{l}\text { Sample } \\
\text { size }\end{array}$} & \multicolumn{2}{|c|}{ Size $(\mathrm{cm})$} \\
\hline & & & Latitude & Longitude & & Range & Mean (SD) \\
\hline Ganga & $\begin{array}{c}\text { Azad } \\
\text { Nagar Kanpur } \\
\text { district }\end{array}$ & $\begin{array}{c}\text { Uttar } \\
\text { Pradesh }\end{array}$ & 26.50 & 80.31 & 29 & $\begin{array}{r}10.00- \\
37.50\end{array}$ & $18.96(06.45)$ \\
\hline Godavari & $\begin{array}{c}\text { Peddapalli, } \\
\text { Adilabad } \\
\text { district }\end{array}$ & Telangana & 18.79 & 79.90 & 36 & $\begin{array}{r}08.75- \\
16.26\end{array}$ & $12.64(01.62)$ \\
\hline Narmada & $\begin{array}{c}\text { Uda, } \\
\text { Hoshangabad } \\
\text { district } \\
\end{array}$ & $\begin{array}{l}\text { Madhya } \\
\text { Pradesh }\end{array}$ & 22.35 & 77.13 & 33 & $\begin{array}{r}09.30- \\
25.90\end{array}$ & $15.33(03.89)$ \\
\hline Mahanadi & $\begin{array}{c}\text { Tribhona, Raigarh } \\
\text { district }\end{array}$ & Chhattisgarh & 21.70 & 83.38 & 56 & $\begin{array}{r}06.84- \\
20.90\end{array}$ & $14.19(04.39)$ \\
\hline
\end{tabular}

\section{Figures}




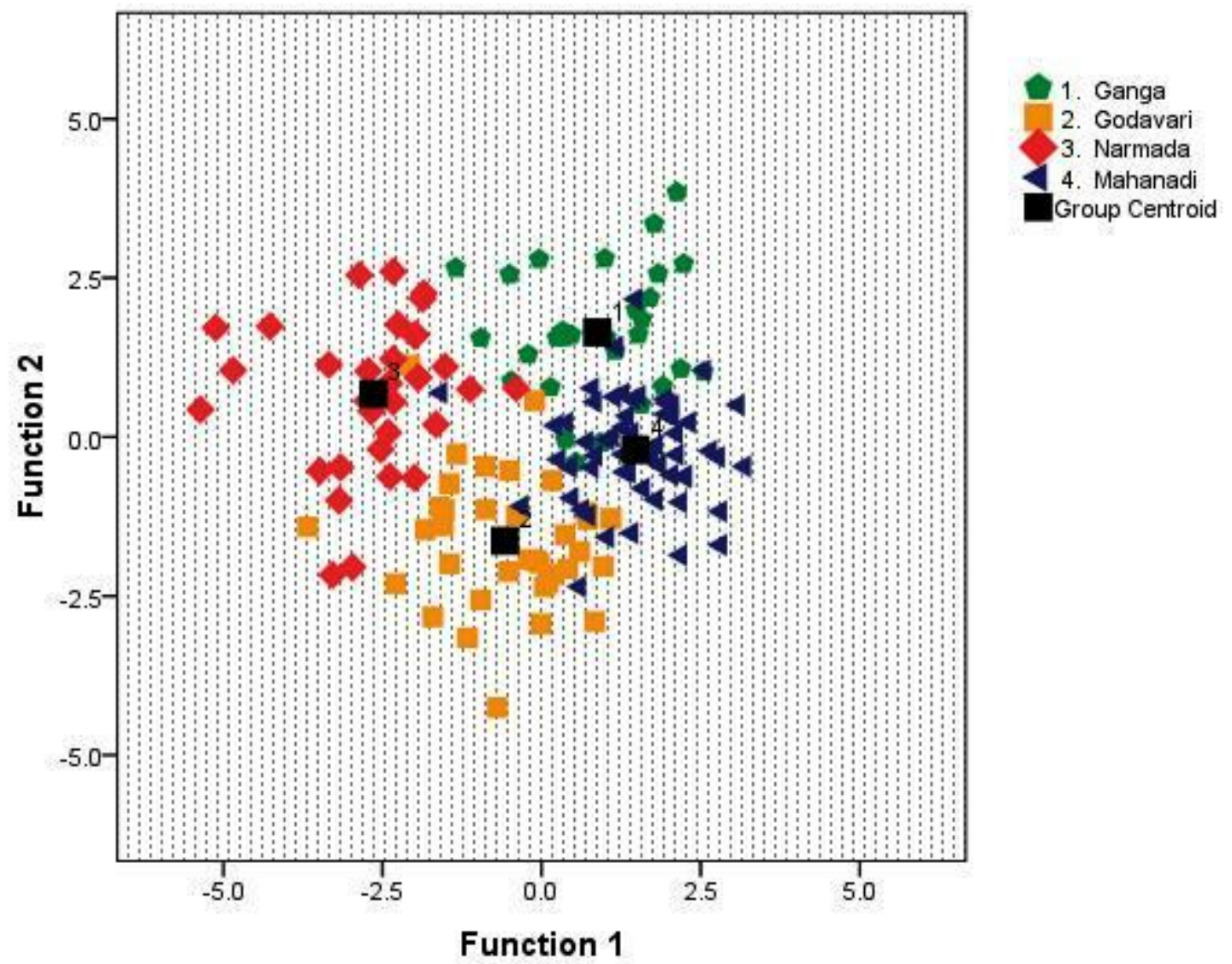

Figure 1

Discriminant function plot based on from DFA of 13 truss-based morphometric distances variables. (Group Centroids; 1: Ganga; 2: Godavari; 3: Narmada; 4: Mahanadi) 


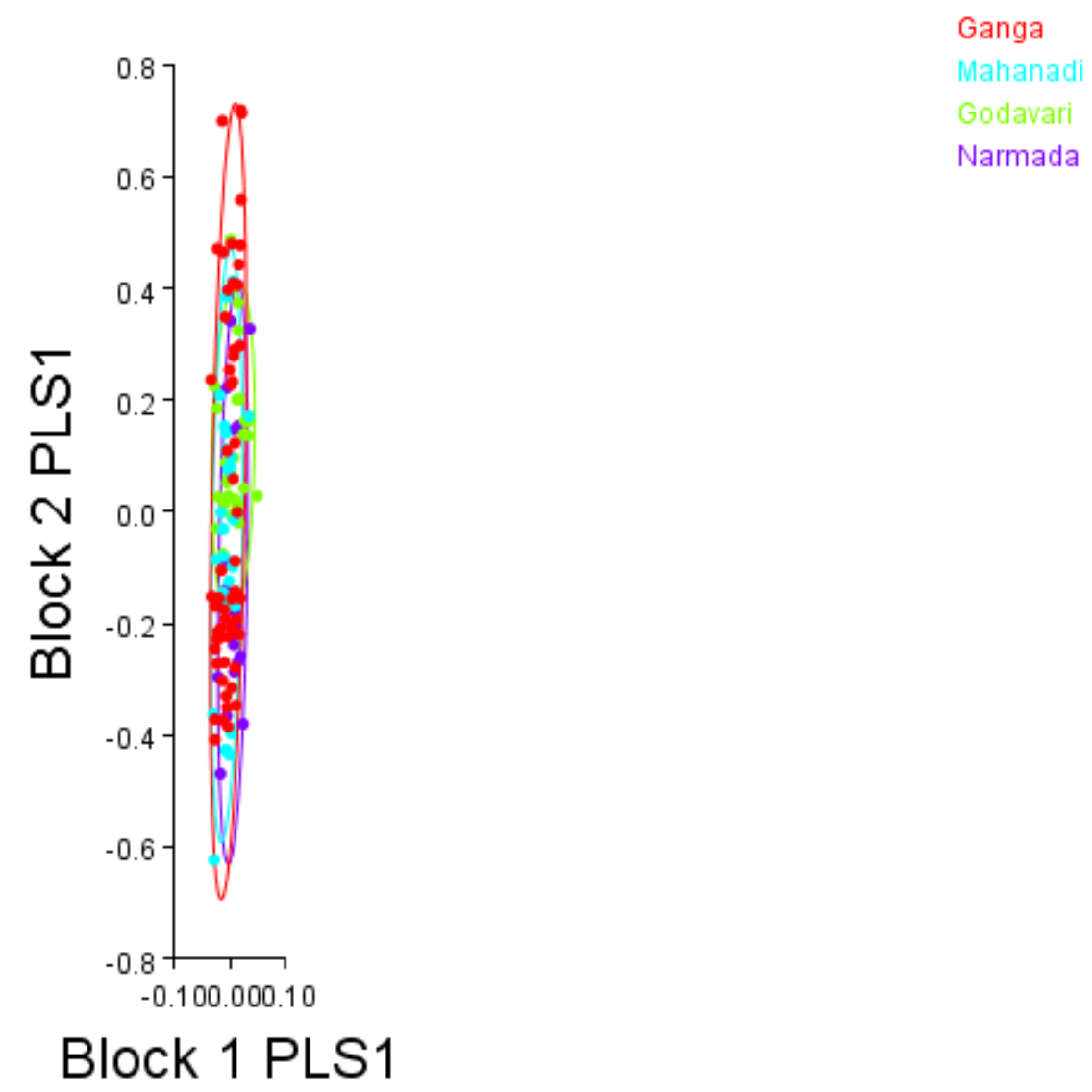

Figure 2

Scatter plot of the partial least square analysis in S. Sarana computed on shape (Block1 PLS1) and size (Block2 PLS1) variables 


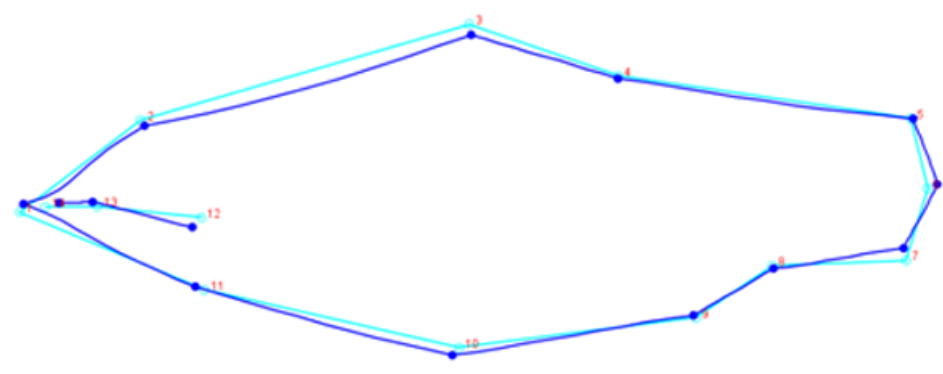

Ganga-Godavari

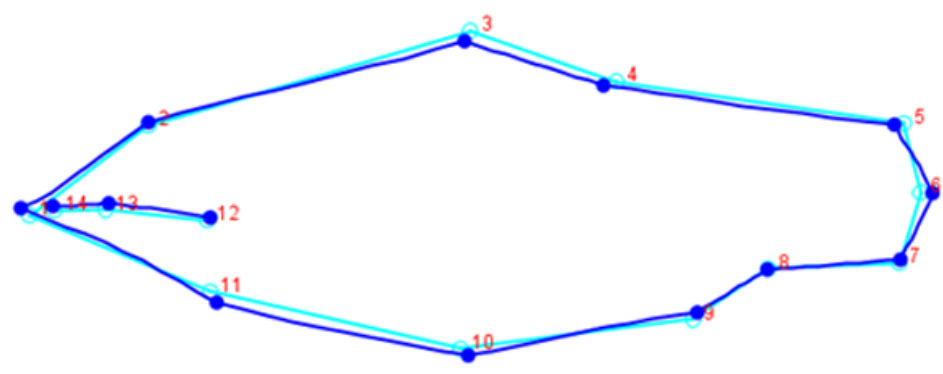

Ganga-Narmada

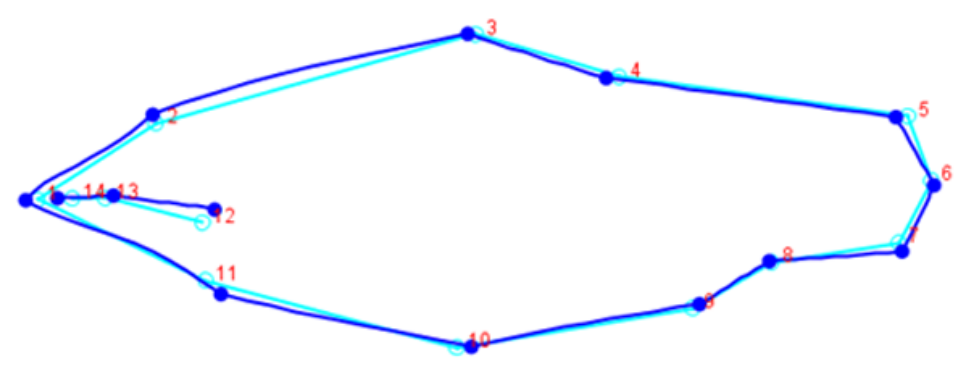

Godavari-Narmada

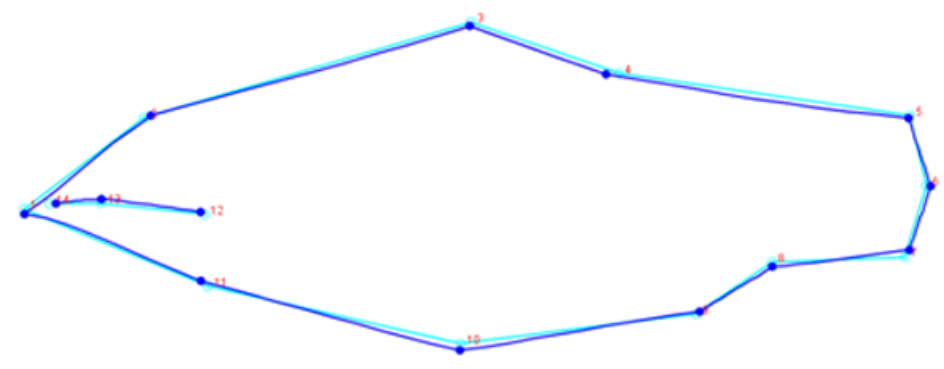

Ganga-Mahanadi

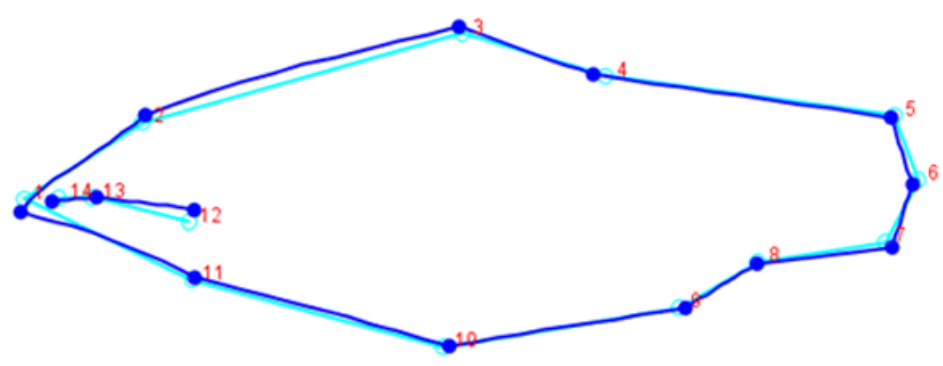

Godavari-Mahanadi

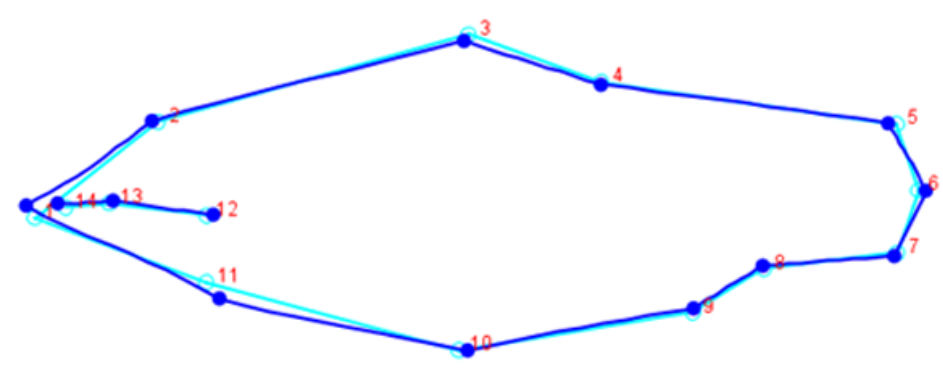

Mahanadi-Narmada

\section{Figure 3}

Deformation grid of wireframe graph showing the variation of the body shapes among populations of S. sarana 


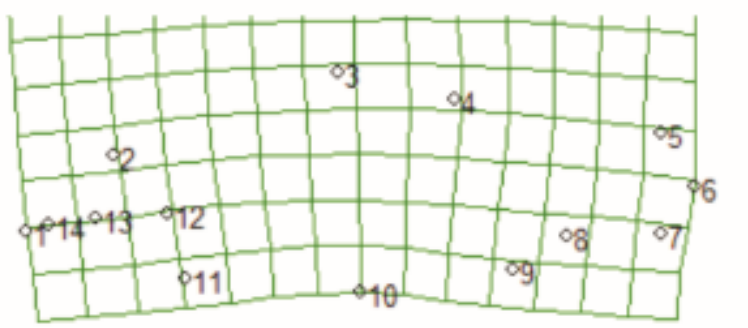

\section{Ganga}
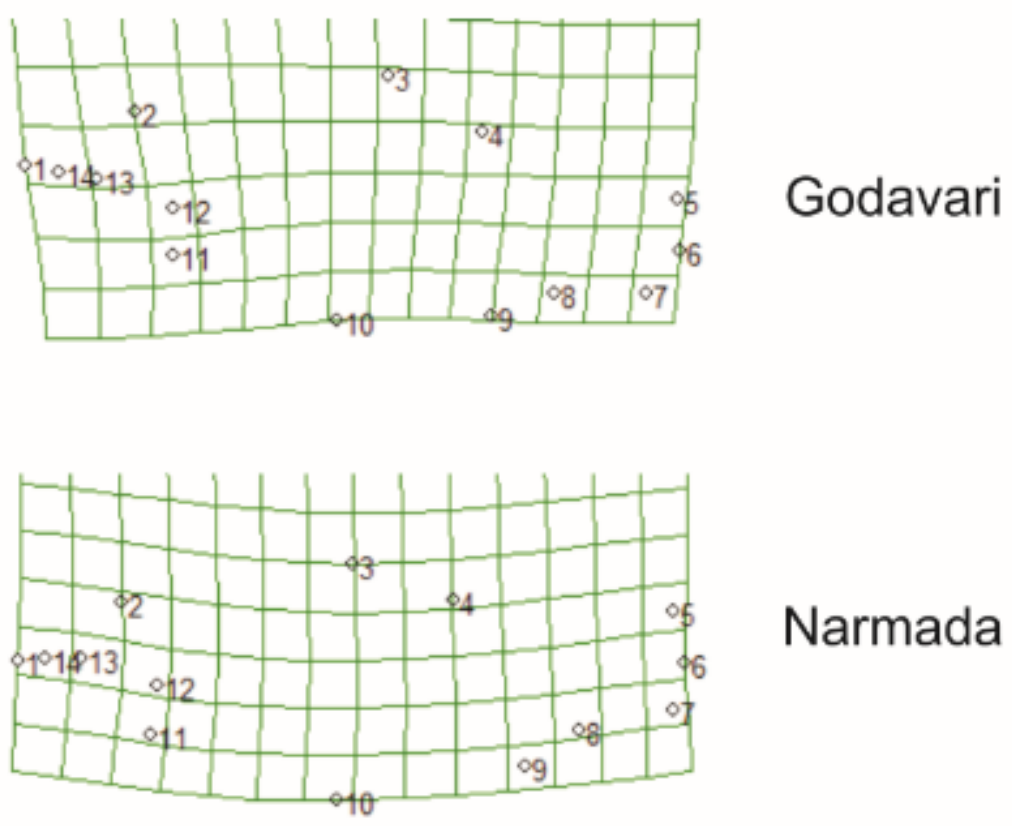

Narmada

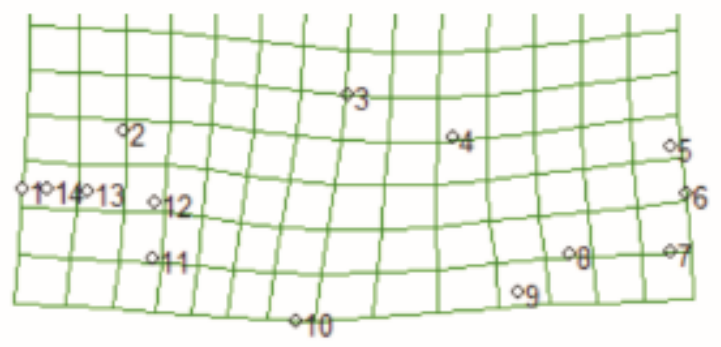

\section{Mahanadi}

\section{Figure 4}

Deformation grid of relative warps graph showing the variation of the body shapes among populations of S. sarana 


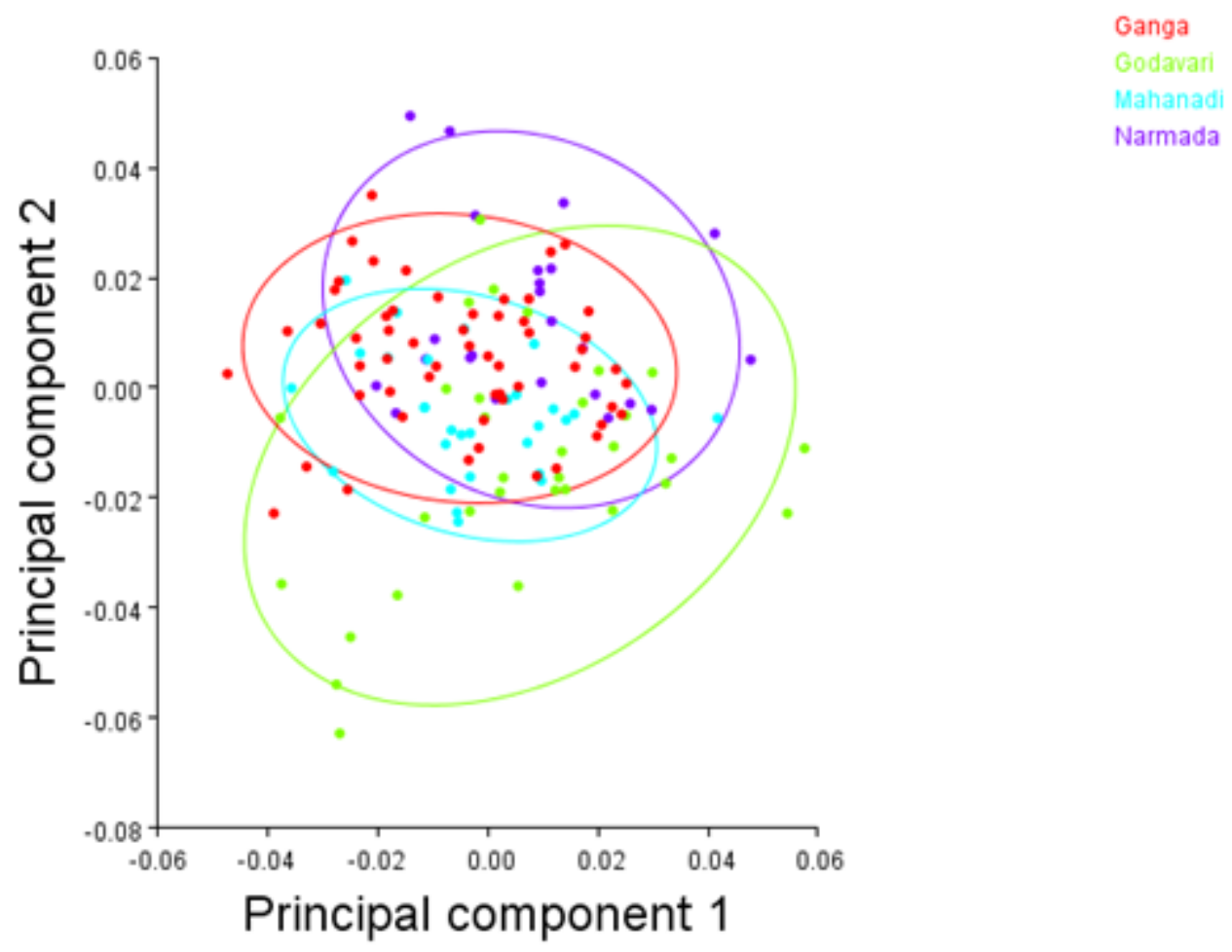

Figure 5

Plot of principal component analysis for S. sarana populations showing loadings of each sample on the first two principal components 


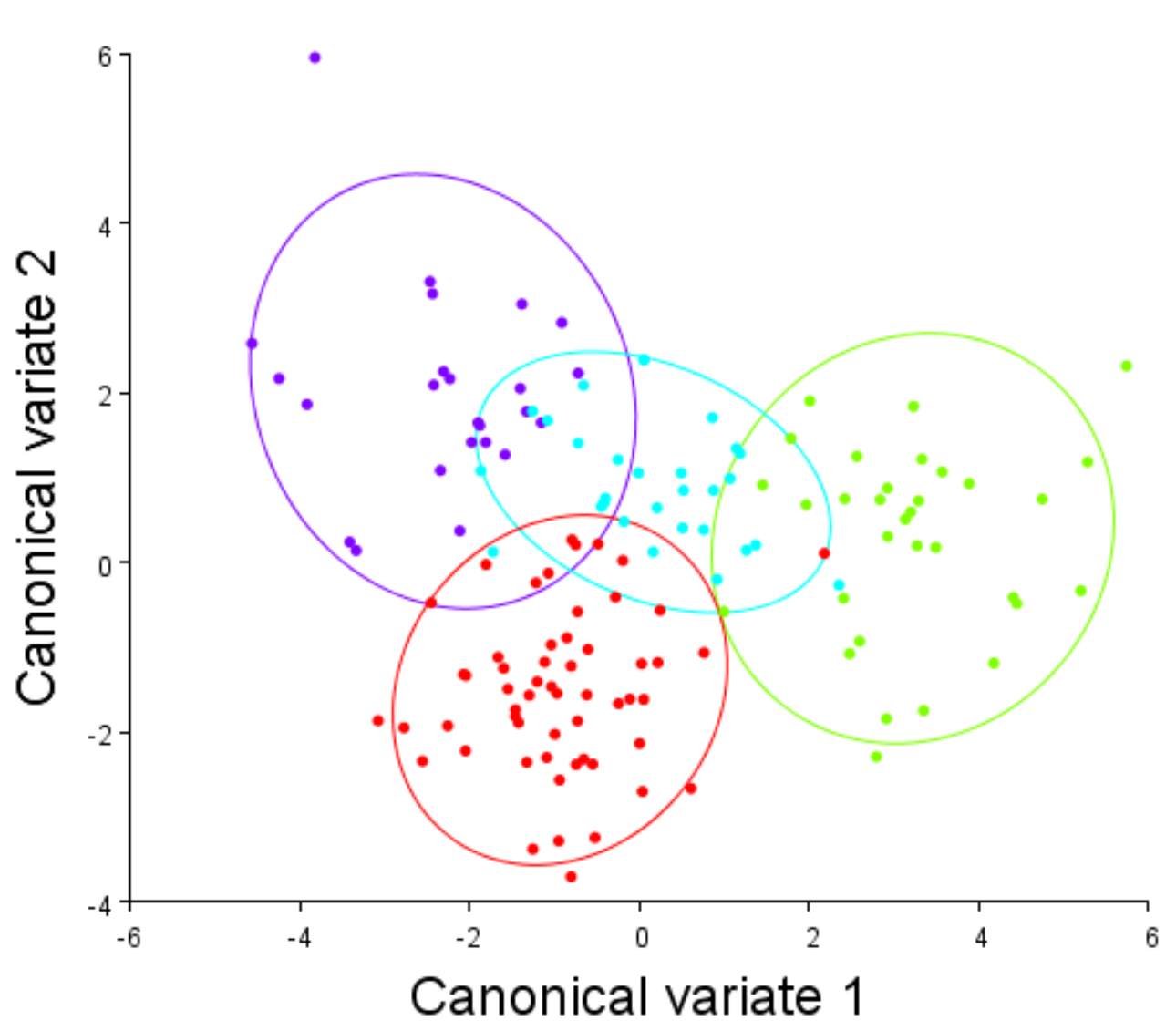

Ganga

Godavari

Mahanadi

Narmada

Figure 6

Plot of canonical variate analysis for $\mathrm{S}$. sarana populations showing frequency of specimen distribution in respective group on the first two axis 

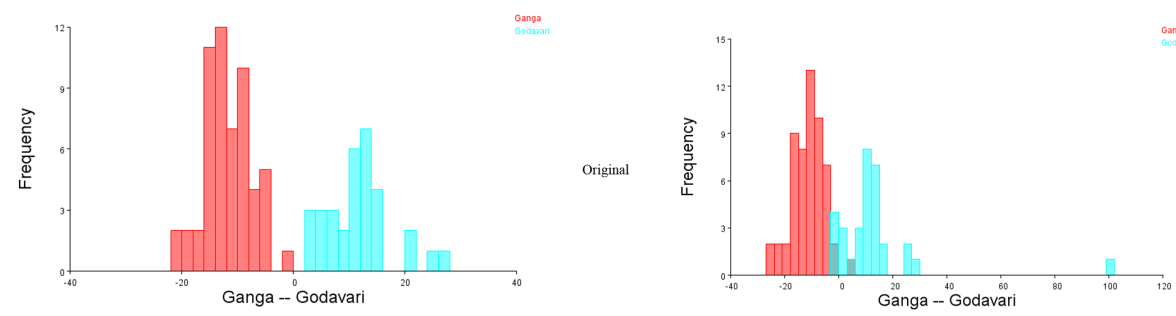

Cross validated
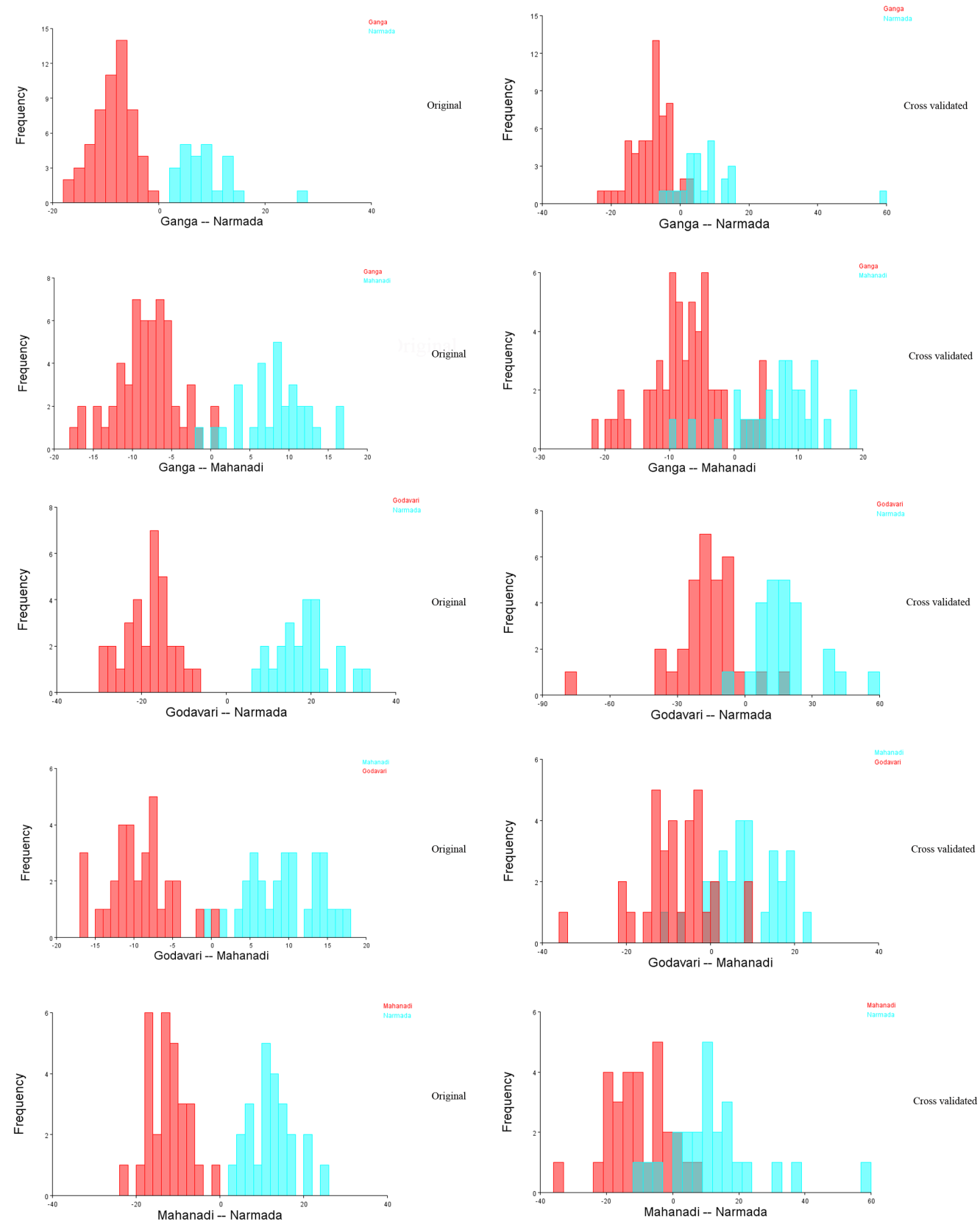

Figure 7

Discriminant function analysis from geometric morphometric variables showing original and crossvalidation bar plots of S. sarana body shape between populations (Ganga- Godavari, Ganga-Narmada, Ganga-Mahanadi, Godavari-Narmada, Godavari-Mahanadi, Mahanadi-Narmada) 


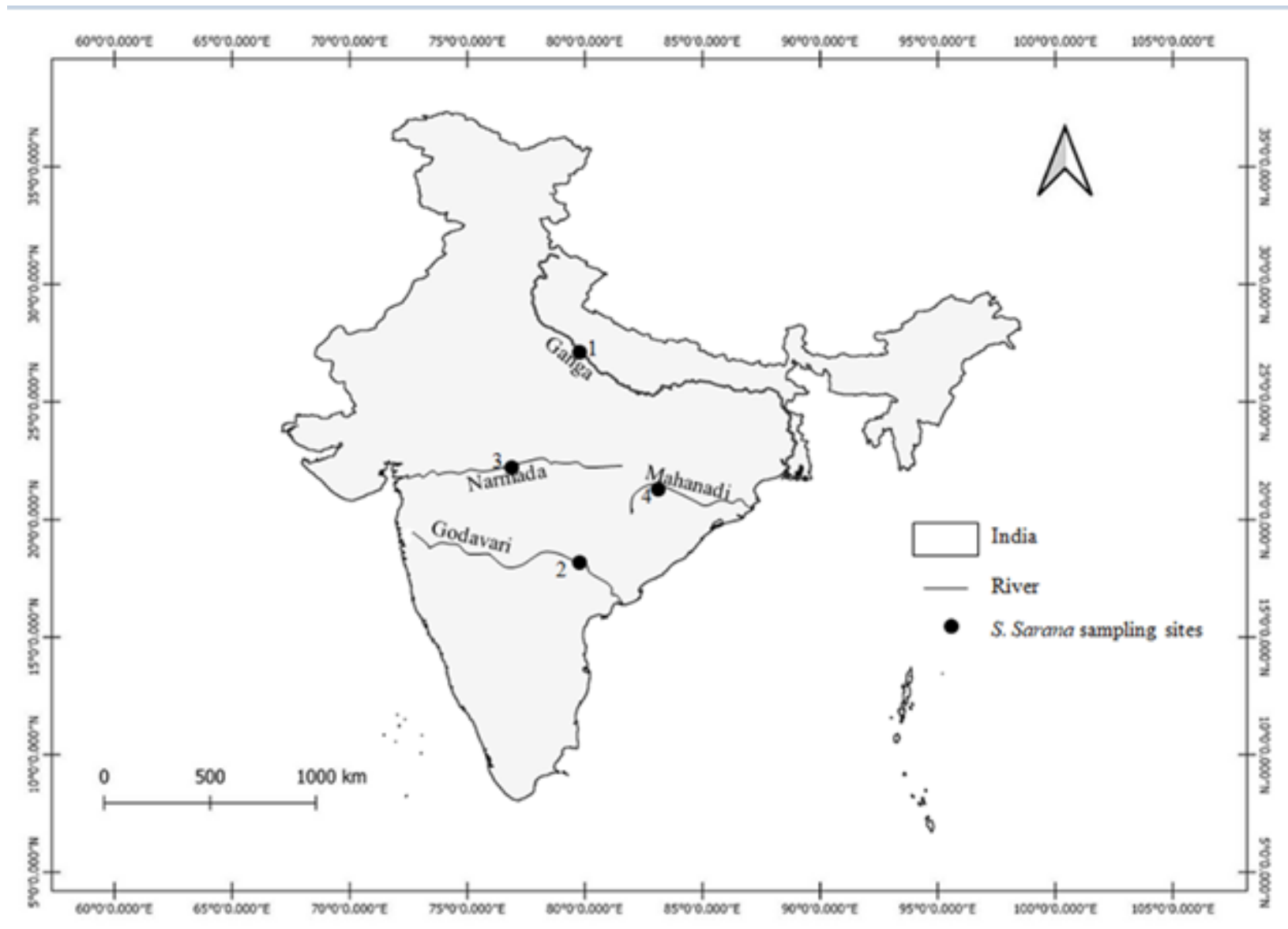

Figure 8

Map depicting sampling sites for the S. sarana populations from four rivers of India. Sampling sites (River); 1: Azad Nagar, Kanpur (Ganga), 2: Peddapalli, Adilabad (Godavari), 3: Uda, Hoshangabad (Narmada), 4: Tribhona, Raigarh (Mahanadi). The map was designed by Deepmala Gupta

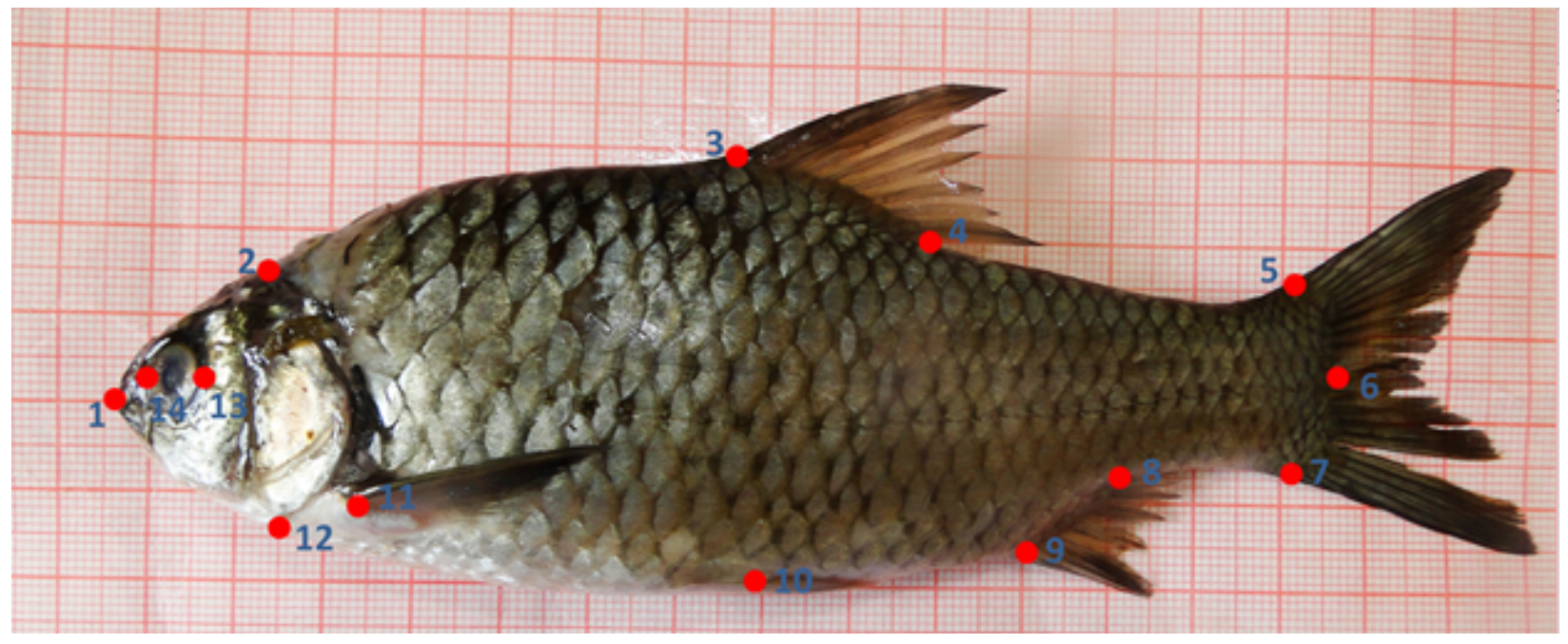

Figure 9

Fourteen landmarks employed for analysis of morphological variation in S. sarana. Landmarks refer to: (1) anterior tip of snout at upper jaw (2) most posterior aspect of neurocranium (beginning of scaled 
nape) (3) origin of dorsal fin (4) end of dorsal fin (5) anterior attachment of dorsal membrane from caudal fin (6) posterior end of vertebrae column (7) anterior attachment of ventral membrane from caudal fin (8) end of anal fin (9) origin of anal fin (10) insertion of pelvic fin (11) insertion of pectoral fin (12) end of operculum (13) posterior end of eye (14) anterior end of eye 